(2) Open Access Full Text Article

\title{
Pentoxifylline and electromagnetic field improved bone fracture healing in rats
}

This article was published in the following Dove Press journal:

Drug Design, Development and Therapy

9 September 2015

Number of times this article has been viewed

\author{
Yusuf Atalay' \\ Nedim Gunes ${ }^{2}$ \\ Mehmet Dervis Guner ${ }^{3}$ \\ Veysi Akpolat ${ }^{4}$ \\ Mustafa Salih Celik ${ }^{4}$ \\ Rezzan Guner ${ }^{2}$ \\ 'Department of Oral and Maxillofacial \\ Surgery, Faculty of Dentistry, Afyon \\ Kocatepe University, Afyonkarahisar, \\ ${ }^{2}$ Department of Oral and Maxillofacial \\ Surgery, Faculty of Dentistry, Dicle \\ University, Diyarbakır, ${ }^{3}$ Department \\ of Orthopedics, Medicana Hospitals, \\ Ankara, ${ }^{4}$ Department of Biophysics, \\ Faculty of Medicine, Dicle University, \\ Diyarbakır, Turkey
}

Background: The aim of this study was to evaluate the effects of a phosphodiesterase inhibitor pentoxifylline (PTX), electromagnetic fields (EMFs), and a mixture of both materials on bone fracture healing in a rat model.

Materials and methods: Eighty male Wistar rats were randomly divided into four groups: Group A, femur fracture model with no treatment; Group B, femur fracture model treated with PTX $50 \mathrm{mg} / \mathrm{kg} /$ day intraperitoneal injection; Group C, femur fracture model treated with EMF 1.5 $\pm 0.2 \mathrm{Mt} / 50 \mathrm{~Hz} / 6$ hours/day; and Group D, femur fracture model treated with PTX $50 \mathrm{mg} /$ $\mathrm{kg} /$ day intraperitoneal injection and EMF $1.5 \pm 0.2 \mathrm{Mt} / 50 \mathrm{~Hz} / 6$ hours/day.

Results: Bone fracture healing was significantly better in Group B and Group C compared to Group A $(P<0.05)$, but Group D did not show better bone fracture healing than Group A $(P>0.05)$.

Conclusion: It can be concluded that both a specific EMF and PTX had a positive effect on bone fracture healing but when used in combination, may not be beneficial.

Keywords: bones, electromagnetic fields, fracture healing, phosphodiesterase inhibitor, pentoxifylline, rats

\section{Introduction}

Successful treatment of maxillofacial fractures depends on reduction and fixation to restore the normal occlusion, function, and proper alignment of bones, ${ }^{1}$ and the success of a wide variety of surgical procedures such as repairing jaw fractures, orthognathic surgery, and repairing bone defects also depends on the physiological process of bone fracture healing. Despite progressions in maxillofacial surgery, bone fractures do not always heal successfully. ${ }^{2}$ Therefore, studies in recent years have researched different factors such as growth factors, the applied force values, drug injections, or electrical stimulation, which could be considered to be of benefit in more successful rapid bone remodeling. ${ }^{3}$

Pentoxifylline (PTX) is a competitive non-selective phosphodiesterase inhibitor (PDEI), ${ }^{4}$ which reduces inflammation, and enhances microcirculation, blood flow, and tissue oxygenation. ${ }^{5}$ In addition, PTX improves red blood cell deformability and decreases the potential for platelet aggregation and thrombus formation. ${ }^{6}$ In a previous study, daily injections of PTX have been shown to stimulate bone formation and to increase systemic bone mass in mice. ${ }^{7}$ In another study, Labib and Farid suggested that PTX could be regarded as a valid approach in the management of osseointegration. ${ }^{8}$ In addition, many studies have demonstrated the positive effects of PTX in healing of mandibular. ${ }^{9,10}$ The efficacy of PTX in treatment is essentially due to its potential to increase blood flow and tissue oxygenation with its hemorheologic effects. ${ }^{11}$ Since a vascular response is a prerequisite for successful bone healing physiology, ${ }^{12,13}$ it was
Department of Oral and Maxillofacial

Surgery, Faculty of Dentistry,

Afyon Kocatepe University, 03030

Afyonkarahisar, Turkey

Tel +90 2722167900 ext I025-1038

Email dt_atalay@hotmail.com submit your manuscript | www.dovepress.com

Dovepress

http://dx.doi.org/10.2147/DDDT.S89669
Drug Design, Development and Therapy 2015:9 5195-520I

(c) (i) (-) 2015 Atalay et al. This work is published by Dove Medical Press Limited, and licensed under Creative Commons Attribution - Non Commercial (unported, v3.0) License. The full terms of the License are available at http://creativecommons.org/licenses/by-nc/3.0/. Non-commercial uses of the work are permitted without any further permission from Dove Medical Press Limited, provided the work is properly attributed. Permissions beyond the scope of the License are administered by Dove Medical Press Limited. Information on
how to request permission may be found at: http://www.dovepress.com/permissions.php 
hypothesized that in the current research that PTX might also be beneficial for bone fracture healing.

A variety of non-invasive bone fracture treatment techniques have been used for biophysical stimulation to accelerate and finalize bone healing. ${ }^{14}$ One of these methods is electromagnetic field (EMF) stimulation, a method which has been used in cases of bone fracture healing for over three decades. ${ }^{15-18}$ Although the US Food and Drug Administration have approved EMF therapy as a safe and effective method for treating osteoporosis and as therapy for bone non-union, ${ }^{19,20}$ there are still some controversial results. ${ }^{21,22}$ Despite a long history of clinical use of EMFs and research, there is still poor understanding of the underlying action mechanisms of EMFs and the optimal parameters for usage. However, all researchers have emphasized that in the treatment of various diseases, it is necessary to determine the appropriate frequency and level of EMFs to be able to create gold-standard treatment protocols. ${ }^{23,24}$

To obtain normal functioning of the bone fracture and its surrounding structures, the swift recovery to normal anatomy after reduction is crucial, and an increasing number of studies are researching this subject. ${ }^{25}$ The purpose of the current study was to undertake histological evaluations of the effects of PTX as a peripheral vasodilator, EMF therapy as a biophysical stimulator, and a combination of both materials on the repair process of a femur fracture in a rat model.

\section{Materials and methods}

\section{Study design}

The study included 80 male Wistar albino rats (mean age, 12 weeks; weight $300 \pm 20 \mathrm{~g}$ ) and was conducted at the Health Institution Research Centre, Dicle University, Diyarbakır, Turkey. All animals were acclimatized to laboratory conditions for 2 weeks before beginning the experiments. The animals were individually housed in flexiglass cages in a controlled environment $\left(22^{\circ} \mathrm{C} \pm 2^{\circ} \mathrm{C} ; 12\right.$-hour light-dark cycle) with free access to drinking water and a diet of standard laboratory rat food pellets. The experimental protocol of the study was approved by the Animal Experiment Ethics Committee of Dicle University. The animals were maintained and used in accordance with the animal welfare act and guidance for the care and use of laboratory animals. ${ }^{26}$ The rats were randomly divided into four groups:

- Group A (control group), femur fracture model with no treatment $(n=20)$;

- Group B (PTX group), femur fracture model treated with PTX (50 mg/kg/day) intraperitoneal injection $(n=20)$;
- Group C (EMF group), femur fracture model treated with $\operatorname{EMF}(1.5 \pm 0.2 \mathrm{Mt} / 50 \mathrm{~Hz} / 6$ hours/day) $(\mathrm{n}=20)$; and

- Group D (PTX + EMF group), femur fracture model treated with PTX (50 mg/kg/day) intraperitoneal injection and EMF (1.5 $\pm 0.2 \mathrm{Mt} / 50 \mathrm{~Hz} / 6$ hours/day) $(\mathrm{n}=20)$.

Group A and Group $\mathrm{C}$ received a daily intraperitoneal injection in order to simulate any possible influence of psychical trauma or physical stress on bone healing caused by injection.

\section{Chemicals}

PTX (Trental ${ }^{\circledR} ; 100 \mathrm{mg}$ ampoules) was obtained from SanofiAventis, Bridgewater, NJ, USA; cefazolin sodium (1 g vials) was purchased from Astellas Pharma Inc, Tokyo, Japan; ketamine chlorhydrate $(10 \mathrm{~mL})$ was acquired from Pfizer Inc, New York, NY, USA; and xylazine chlorhydrate $(25 \mathrm{~mL})$ was procured from Bayer AG, Leverkusen, Germany.

\section{Rat femur fracture model and surgical procedure}

Surgical procedures were performed under general anesthesia consisting of a combination of ketamine chlorhydrate $(0.08 \mathrm{~mL} / 100 \mathrm{~g}$ body weight) and xylazine chlorhydrate $2 \%$ ( $0.04 \mathrm{~mL} / 100 \mathrm{~g}$ body weight). In the present study, the open surgery model of experimental fracture healing models was used. In this technique, the fracture is created with a hammer osteotomy, Gigli saw, or electric saw. This technique provides a transverse fracture line and in this respect, is more controlled than closed models. ${ }^{27}$ However, in a previous study of different gap sizes, the callus geometry, tissue differentiation patterns, and fracture stiffness predicted by the model were similar to experimental observations for every analyzed situation. ${ }^{28}$

After positioning the right and left legs in flexion, a longitudinal cutaneous, subcutaneous, and periosteal incision was made $20-25 \mathrm{~mm}$ in length to reach the medial surface of the left femur. Exposing the medial surface of the femur with blunt dissection, the soft tissue was then retracted. Before making the bone incision, a four-holed microplate was adapted to the bone. After fixing the microplate, a bicortical bone incision was made with a $1 \mathrm{~mm}$ diameter fissure and a size 12 stainless steel dental burr (Meisinger, Nuess, Germany) on a low-speed handpiece, under constant sterile saline irrigation starting from the buccal cortical bone. A gap was left between the bone segments up to the thickness of the burr (1 mm) (Figure 1). Then, the rigid stabilization of the fracture segments with the microplate and screws was 


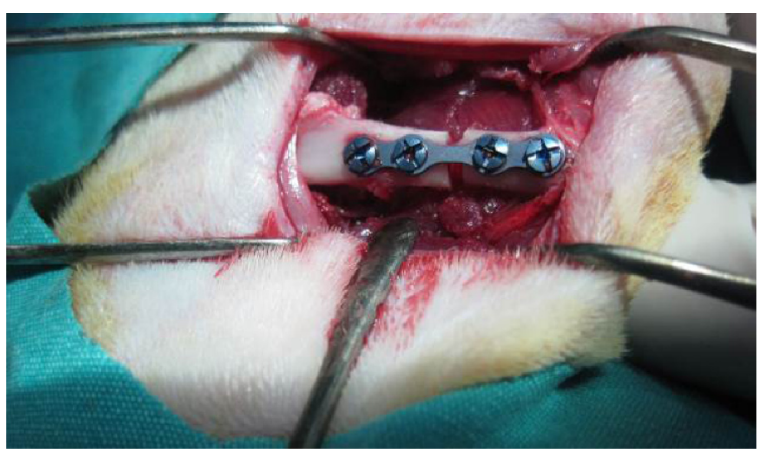

Figure I A photographic image of the surgical procedure showing the gap between the bone segments after fixing the microplate.

checked again. Subcutaneous tissue layers were sutured with resorbable sutures, and the skin was sutured with silk. Upon completion of the surgical procedure, each animal received a single dose of $100 \mathrm{mg} / \mathrm{kg}$ cefazolin sodium antibiotic by intramuscular injection. Following surgery, ten rats per study group were killed at Day 21 and at Day 30 using high-dose ketamine.

\section{EMF and PTX administration}

Published data on the affirmative efficacy of EMF and PTX in rats are in agreement with the daily doses of $50 \mathrm{~Hz}^{29}$ and $50 \mathrm{mg} / \mathrm{kg},{ }^{30}$ respectively, that animals received in the present study. To avoid any outside interference to the magnetic field (MF) during the application of the EMF, the experimental mechanism was placed inside an installed Faraday cage. For the EMF to reach the groups without hindrance, flexiglass cages were used. The EMF was produced by a pair of Helmholtz coils with a wrap-around number of 125 , with internal diameter of $47 \mathrm{~cm}$, and at distance intervals of $70 \mathrm{~cm}$, placed vertically in a Faraday cage. Two identical Helmholtz coils inside the Faraday cage were attached to two identical power sources producing the same voltage and current (48 V, $40 \mathrm{~A})$. Throughout the application of the EMF to the rats, measurements were regularly taken with a digital teslameter (FW Bell Corporation, Orlando, FL, USA) at 15 different points within the flexiglass cage. As a result of the measurements, the mean peak force was determined as $1.5 \pm 0.2 \mathrm{mT}$. After the pulse generator was switched off, the EMF measured in the cage environment, ie, the background, was found to be $1.5 \pm 0.2 \mathrm{mT}, 50 \mathrm{~Hz}$ frequency and peak duration $1.3 \mathrm{~ms}$.

The application of the EMF was started on postoperative Day 1, and was continued once a day every day at $1.5 \pm 0.2 \mathrm{mT}$ intensity and at a frequency of $50 \mathrm{~Hz}$ for 6 hours. Throughout all the applications, an observer visited the study room regularly each hour, and the procedures were continued without interruption. The application of PTX was started on postoperative Day 1, was applied intraperitoneally at $50 \mathrm{mg} / \mathrm{kg} /$ day as a single dose of PTX (Trental ${ }^{\circledR}$ ampoule [100 mg]) once a day every day.

\section{Histopathological evaluations}

Bone regeneration and fibrotic healing were evaluated histopathologically. The rat femurs were fixed in $10 \%$ formaldehyde solution for 48 hours and were decalcified with $5 \%$ nitric acid. The specimens were washed with distilled water, dehydrated with increasing increments of concentrations of ethyl alcohol, cleaned in xylene, and were then embedded in paraffin. Beginning from the center of each specimen, sequential parts were cut parallel to the mid-sagittal defect using a microtome. Transverse sections of 4-5 $\mu \mathrm{m}$ thickness were prepared for each tibia defect and were stained with hematoxylin and eosin. The tissue samples were assessed by a pathologist using a light microscope. The pathologist was blinded to the treatment group that each specimen came from. A 10-point scale ${ }^{31}$ was used for evaluation of bone healing, where tissue was scored according to the histopathological findings in the healing zone, as follows:

- 1 point, only fibrous tissue;

- 2 points, predominantly fibrous tissue;

- 3 points, equal amounts of fibrous and cartilage tissue;

- 4 points, predominantly cartilage tissue with little fibrous tissue;

- 5 points, only cartilage tissue;

- 6 points, predominantly cartilage tissue with little immature bone;

- 7 points, equal amounts of cartilage and immature bone tissue;

- 8 points, predominantly immature bone with little cartilage tissue;

- 9 points, healing with immature bone; and

- 10 points, healing with mature bone.

Four slides were examined from each fracture. The mean histological score was calculated for each treatment group.

\section{Statistical analysis}

The data obtained for all the parameters to be evaluated were transferred to SPSS for Windows, version 15.0 (SPSS Inc, Chicago, IL, USA) program for statistical analysis. For the comparison of paired parameters for independent variables, the Mann-Whitney $U$-test was used as a two-way nonparametric test. In all tests, a value of $P<0.05$ was accepted as statistically significant. 


\section{Results}

None of the rats died in any of the groups during the course of the experiment. No unwanted condition developed in any rat, and none of the rats was excluded from the study. All of the animals tolerated the procedure well and demonstrated good homeostasis and rapid recovery from anesthesia.

\section{Histopathological results}

Comparison of histopathological bone fracture healing scores among all groups at Day 21 and Day 30 is shown in Table 1 and Figure 2. In all groups ten of the rats were sacrificed at day 21 and other ten rats were sacrificed at day 30 . In the histological examination, a larger increase was observed in the cartilage and bone volumes in the EMF and PTX groups than in the control groups (Figures 3-5). Using pairwise comparisons, there was no statistically significant difference between Group B (PTX) at Day 21 and Day 30 and Group C (EMF) at Day 21 and Day $30(P>0.05)$. The level of bone healing in Group B (PTX) and Group C (EMF) was significantly higher than that of Group A (control) at Day $21(P<0.05)$. There was also significantly better healing in Group B (PTX) and Group $\mathrm{C}(\mathrm{EMF})$ than in Group A (control) at Day $30(P<0.05)$.

\section{Discussion}

Swift bone fracture healing after traumas and surgical procedures is crucial in order to regain normal functioning of the bone and its surrounding structures. ${ }^{32}$ There have been an increasing number of studies on this subject. ${ }^{25,32}$ Although the outcome of various clinical and surgical procedures in bone healing is affected by several factors, which may be patient-, defect-, or surgery-related variables, ${ }^{32}$ blood flow and circulation play a significant role in the process of bone remodeling and the reparative regeneration of bone tissue..$^{33,34}$ After the third day of the fracture in our current study, there was a significant rise in local blood flow, which is associated with vascular proliferation in the formation of fracture callus. Such changes in flow are likely to be secondary to locally

Table I Statistical analysis of bone healing at Day 2 I and Day 30

\begin{tabular}{lllll}
\hline Study groups & Group A & Group B & Group C & Group D \\
\hline Day 2I $(\mathrm{n}=10)$ & $6.30 \pm 1.059$ & $7.20 \pm 0.632$ & $7.60 \pm 1.075$ & $5.40 \pm 1.265$ \\
$P$-value & & $0.009^{\mathrm{a}, *}$ & $0.006^{\mathrm{b}, *}$ & $0.144^{\mathrm{c}}$ \\
Day 30 $(\mathrm{n}=10)$ & $6.50 \pm 0.843$ & $7.80 \pm 1.317$ & $7.80 \pm 0.919$ & $5.90 \pm 1.101$ \\
$P$-value & & $0.038^{\mathrm{a}, *}$ & $0.01 \mathrm{I}^{\mathrm{b}, *}$ & $0.160^{\mathrm{c}}$ \\
$P$-value & & $0.203^{\mathrm{d}}$ & $0.250^{\mathrm{e}}$ & $0.622^{\mathrm{f}}$ \\
\hline
\end{tabular}

Notes: *Statistically significant between-group difference $(P<0.05$, Mann-Whitney $U$-test). Data are shown as mean \pm standard deviation. a Group B compared with group A. 'broup C compared with group A. 'Group D compared with group A. ${ }^{\mathrm{d}}$ Group B compared at Day $2 \mathrm{I}$ and Day $30 .{ }^{\mathrm{e}}$ Group $\mathrm{C}$ compared at Day $2 \mathrm{I}$ and Day 30. fGroup D compared at Day 21 and Day 30.

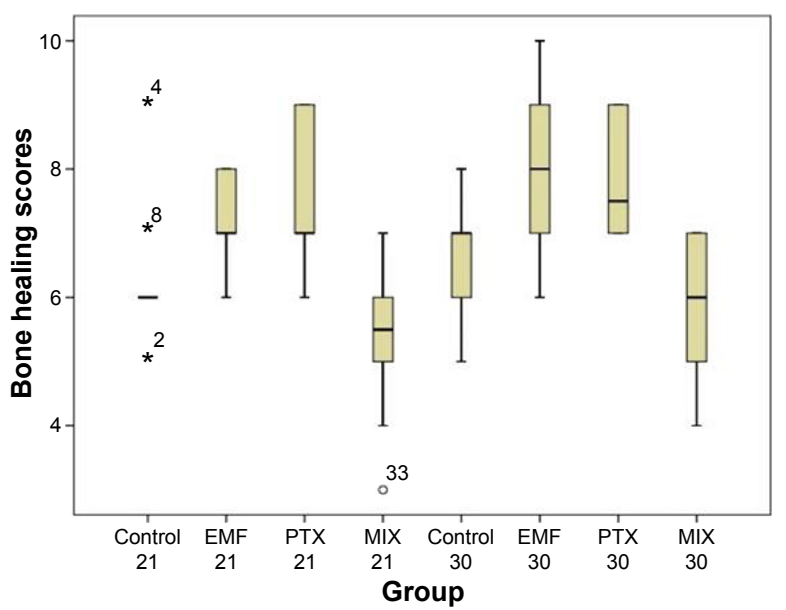

Figure 2 Comparison of histopathological bone-healing scores among groups according to the Huo scale.

Notes: *Contradictory values; - median value of control 21 group.

Abbreviations: EMF, electromagnetic field; PTX, pentoxifylline; MIX, both EMF and PTX treatment.

controlled vasoreactivity of pre-existing vessels, as opposed to that of newly formed angiogenic vessels. ${ }^{34}$

The present study aimed to evaluate the possible effects of PTX as a PDEI and EMFs on bone fracture healing. The efficacy of PTX and a specific EMF on the bone-healing stage of a femoral fracture model in rats was evaluated through histopathological analyses.

PDEIs provides increased blood flow via the nitric oxide (NO) pathway in the process of bone healing. ${ }^{34} \mathrm{NO}$ is a highly reactive free radical involved in inflammation, arthritis, and bone fracture healing. It is known that NO has a regulatory role in blood flow and perfusion pressure to isolate vascular beds in response to appropriate physiological stimuli. ${ }^{35}$ Therefore, treatment modalities applied to improve the blood circulation may improve the outcomes of bone healing. Thus, the current study focused on the impact of PTX as a peripheral vasodilator on bone fracture healing. The results

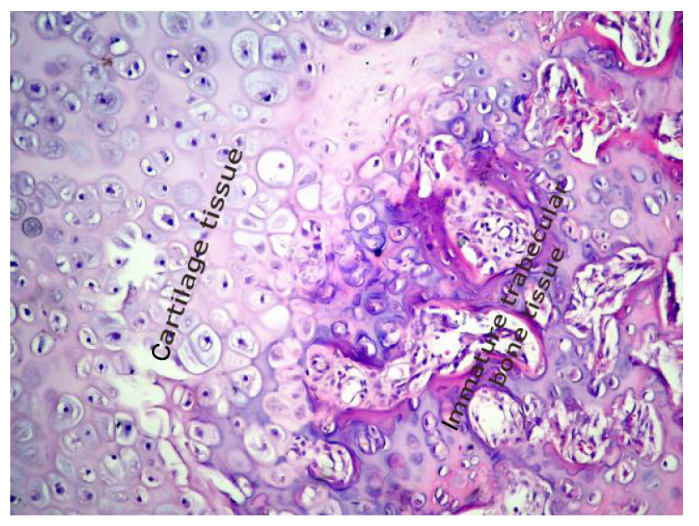

Figure 3 Histopathological sample of bone tissue. The sample shows mostly cartilage and a little newly formed, immature bone tissue.

Notes: The sample is stained with hematoxylin and eosin; magnification, 200x. 


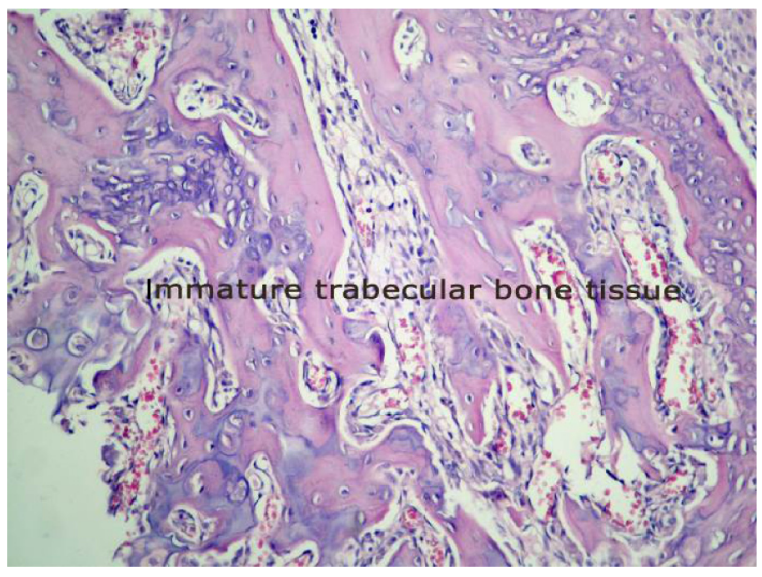

Figure 4 Histopathological sample of bone tissue. The sample shows mostly immature bone tissue.

Notes: The sample is stained with hematoxylin and eosin; magnification, 200x.

of this study have shown that PTX had a positive effect on bone fracture healing.

Studies that have examined the role of PDEIs involved in vascular response related to bone healing have reported results comparable to the findings of the present investigation. The administration of two PDEIs, tadalafil and vardenafil, have been shown to result in reduced bone mass, evidenced by in vitro cell culture and in vivo animal models, ${ }^{36,37}$ and the beneficial effects of the PDEI sildenafil on bone healing have been previously shown..$^{34,37}$ In a study by Aydin et al ${ }^{30}$ in which the same dose of PTX was applied as in the current study, it was suggested that the hematoma stage of fracture healing, which is the first phase, might be promoted by PTX. At Day 21, it was thought that the anti-inflammatory effects of PTX might have delayed fracture healing. ${ }^{30}$ However, in the current study, in complete contrast, positive results of

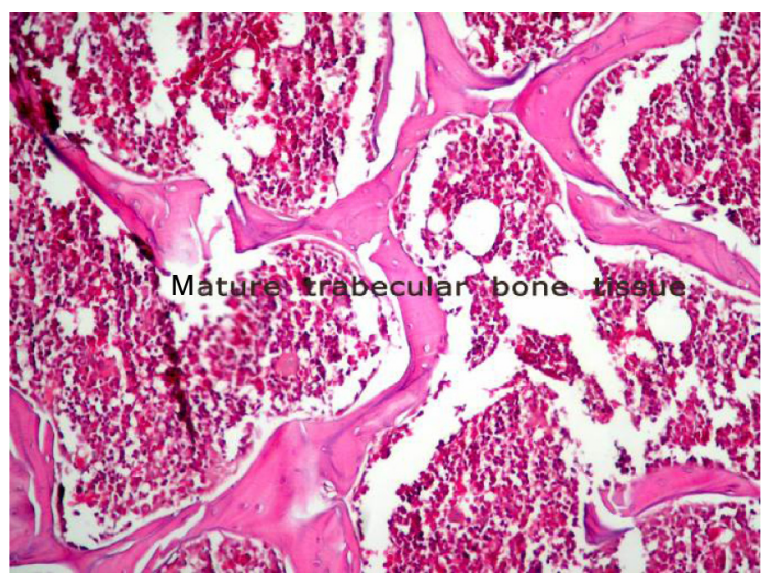

Figure 5 Histopathological sample of bone tissue. The sample is mostly mature bone tissue.

Notes: The sample is stained with hematoxylin and eosin; magnification, 200x. bone healing were obtained at Day 21. Despite the numerous studies on the subject, there is insufficient knowledge about the effects of PDEI use on bone healing metabolism.

For many years, EMFs have been researched as a stimulation method to enhance bone regeneration in maxillofacial surgery, including dental implants, distraction osteogenesis, and bone grafts. ${ }^{21,38,39}$ The knowledge from recent studies ${ }^{40,41}$ has conclusively demonstrated that the contribution of EMFs to the bone healing process is based on stimulating the expression of growth factors, such as vascular endothelial growth factor and bone morphogenetic protein. EMFs also induce angiogenesis, migration, proliferation, and differentiation of stem cells from the surrounding mesenchymal tissues into cartilage and bone-forming cells in an area of injury. ${ }^{40,41}$ The beneficial effects of the methods of electromagnetic stimulation have been widely documented. Selecting the parameters (intensity, frequency, etc) likely to have maximum benefits in EMF therapy has been especially complicated, ${ }^{42}$ because EMFs may influence bone healing through a variety of pathways. In addition, EMF therapy has been reported to have benefits in fracture healing, ${ }^{22}$ and healing of osteotomies, ${ }^{43}$ pseudoarthrosis, ${ }^{43}$ osteoporosis, and the deleterious effects of poor bone mineral density. ${ }^{44}$

Most published studies suggest that EMFs have a positive effect on bone healing, ${ }^{22,43,45-48}$ while some studies have reported different results. ${ }^{21,49-51}$ The scientific evidence regarding the efficacy and efficiency of EMFs is still controversial. However, in a study by Fredericks et $\mathrm{al}^{38}$ it was claimed that low-frequency and low-intensity EMFs are powerful in the acceleration and finalization of bone fracture healing. Similarly, in the present study, it was observed that low-frequency and low-intensity EMF $(1.5 \pm 0.2 \mathrm{mT}, 50 \mathrm{~Hz})$ significantly improved fracture healing in rats treated with EMF in the remodeling phase following treatment, compared with the control group. Controversial results regarding the effectiveness of EMFs on bone and other tissues may partly be due to the wide variations in type, frequency, duration, magnetic intensity, stimulation period length, and dose. ${ }^{52}$ Differences in the results of the studies might also be related to the study design.

There are limited data about experimental studies that use the PTX and EMF combination for the treatment of bone fracture healing. In the current study, in all the groups to which combined therapy was applied, negative results were evident in bone fracture healing. These results may have arisen due to the unfavorable effects of MFs on NO metabolites. A study by Okano et $\mathrm{al}^{53}$ demonstrated that MF decreased plasma levels of NO metabolites. From the results 
of this study, it could be considered that the regulatory role of NO on the blood flow was suppressed by the EMF, and therefore the bone fracture healing was not successful.

There are some limitations to this study. A single dose of PTX $(50 \mathrm{mg} / \mathrm{kg} /$ day $)$ and EMF $(1.5 \pm 0.2 \mathrm{Mt} / 50 \mathrm{~Hz} /$ 6 hours/day) was applied to the rats, and therefore there can be speculation as the effects on bone fracture healing of different dosages. However, due to ethical restrictions, a larger number of animals could not be used. Other limitations were that histopathological results could not be supported by biochemical and radiological findings; the monitoring period was relatively short; and there was no hemodynamic monitoring of the animals during the experiment. There is a need for further studies to clarify the mechanism of the effect of EMFs and PTX on bone remodeling.

\section{Conclusion}

It can be concluded that separate application of both PTX as a peripheral vasodilator and a specific EMF as a biophysical stimulator had a positive effect on bone fracture healing, but when used in combination, there may be no benefits. However, the efficacy of both treatments was modest, and the overall bone healing process could not be completely explained.

\section{Acknowledgment}

This study was supported by the Scientific Research Projects of Dicle University.

\section{Disclosure}

The authors report no conflicts of interest in this work.

\section{References}

1. Shokier H, Khalifa G, Fawzy A, Sallam MM. Experimental use of autogenous bone grafts as an alternative method for bone plates in treatment of mandibular fracture. Aust J Basic Appl Sci. 2010;4:1466-1472.

2. Uçan M, Koparal M, Ağaçayak S, et al. Influence of caffeic acid phenethyl ester on bone healing in a rat model. J Int Med Res. 2013;41:1648-1654.

3. Cook JJ, Summers NJ, Cook EA. Healing in the new millennium: bone stimulators: an overview of where we've been and where we may be heading. Clin Podiatr Med Surg. 2015;32:45-59.

4. Essayan DM. Cyclic nucleotide phosphodiesterases. J Allergy Clin Immunol. 2001;108:671-680.

5. Delanian S, Porcher R, Rudant J, Lefaix JL. Kinetics of response to long-term treatment combining pentoxifylline and tocopherol in patients with superficial radiation-induced fibrosis. J Clin Oncol. 2005;23:8570-8579.

6. Ward A, Clissold SP. Pentoxifylline. A review of its pharmacodynamic and pharmacokinetic properties, and its therapeutic efficacy. Drugs. 1987;34:50-97.

7. Kinoshita T, Kobayashi S, Ebara S, et al. Phosphodiesterase inhibitors, pentoxifylline and rolipram, increase bone mass mainly by promoting bone formation in normal mice. Bone. 2000;27:811-817.
8. Labib GS, Farid RM. Osteogenic effect of locally applied Pentoxyfilline gel: in vitro and in vivo evaluations. Drug Deliv. Epub 2014 Feb 20.

9. Kahenasa N, Sung EC, Nabili V, Kelly J, Garrett N, Nishimura I. Resolution of pain and complete healing of mandibular osteoradionecrosis using pentoxifylline and tocopherol: a case report. Oral Surg Oral Med Oral Pathol Oral Radiol. 2012;113:e18-e23.

10. Delanian S, Depondt J, Lefaix JL. Major healing of refractory mandible osteoradionecrosis after treatment combining pentoxifylline and tocopherol: a phase II trial. Head Neck. 2005;27:114-123.

11. Ward A, Clissold SP. Pentoxifylline. A review of its pharmacodynamic and pharmacokinetic properties, and its therapeutic efficacy. Drugs. 1987;34:50-97.

12. Colnot $\mathrm{C}, \mathrm{Lu} \mathrm{C}, \mathrm{Hu} \mathrm{D}$, Helms JA. Distinguishing the contributions of the perichondrium, cartilage, and vascular endothelium to skeletal development. Dev Biol. 2004;269:55-69.

13. Hausman M, Schaffler M, Majeska R. Prevention of fracture healing in rats by an inhibitor of angiogenesis. Bone. 2001;29:560-564.

14. Chao E, Inoue N. Biophysical stimulation of bone fracture repair, regeneration and remodelling. Eur Cell Mater. 2003;6:72-84.

15. Nolte PA, van der Krans A, Patka P, Janssen IM, Ryaby JP, Albers GR. Low-intensity pulsed ultrasound in the treatment of nonunions. J Trauma. 2001;51:693-703.

16. Bassett CA, Mitchell SN, Gaston SR. Pulsing electromagnetic field treatment in ununited fractures and failed arthrodeses. JAMA. 1982;247:623-628.

17. Massari L, Caruso G, Sollazzo V, Setti S. Pulsed electromagnetic fields and low intensity pulsed ultrasound in bone tissue. Clin Cases Miner Bone Metab. 2009;6:149-154.

18. Wang Y, Qin QH. A theoretical study of bone remodelling under PEMF at cellular level. Comput Methods Biomech Biomed Engin. 2012;15:885-897.

19. Chao EY, Inoue N, Koo TK, Kim Y. Biomechanical considerations of fracture treatment and bone quality maintenance in elderly patients and patients with osteoporosis. Clin Orthop Relat Res. 2004;425:12-25.

20. Funk RH, Monsees T, Ozkucur N. Electromagnetic effects-From cell biology to medicine. Prog Histochem Cytochem. 2009;43:177-264.

21. do Nascimento C, Issa JP, Mello AS, de Albuquerque Junior RF. Effect of electromagnetic field on bone regeneration around dental implants after immediate placement in the dog mandible: a pilot study. Gerodontology. 2012;29:e1249-e1251.

22. Shi HF, Xiong J, Chen YX, et al. Early application of pulsed electromagnetic field in the treatment of postoperative delayed union of long-bone fractures: a prospective randomized controlled study. $B M C$ Musculoskelet Disord. 2013;14:35.

23. Ryaby JT. Clinical effects of electromagnetic and electric fields on fracture healing. Clin Orthop Relat Res. 1998;355:S205-S215.

24. Trock DH. Electromagnetic fields and magnets: investigational treatment for musculoskeletal disorders. Rheum Dis Clin North Am. 2000;26:51-62.

25. Anitua E, Sánchez M, Orive G, Andía I. The potential impact of the preparation rich in growth factors (PRGF) in different medical fields. Biomaterials. 2007;28:4551-4560.

26. Clark JD, Gebhart GF, Gonder JC, Keeling ME, Kohn DF. The 1996 guide for the care and use of laboratory animals. ILAR journal. 1997; 38(1):41-48.

27. Öztuna V. Ortopedi ve Travmatolojide Kullanılan Deneysel Hayvan Modelleri (Temel ilkeler, Etik unsurlar ve Modeller) [Experimental Animal Models Used in Orthopedics and Traumatology (basic principles, ethical elements and Models)] (2007) Cilt: 6 Sayi: 1-2. Turkish Association of Orthopaedics and Traumatology. Available from: http://www.totbid.org.tr/files/ONLIB/6_1-2/5.pdf. Turkish.

28. Gómez-Benito M, García-Aznar J, Kuiper J, Doblaré M. Influence of fracture gap size on the pattern of long bone healing: a computational study. J Theor Biol. 2005;235:105-119.

29. Sert C, Mustafa D, Düz MZ, Akşen F, Kaya A. The preventive effect on bone loss of 50-Hz, 1-mT electromagnetic field in ovariectomized rats. J Bone Miner Metab. 2002;20:345-349. 
30. Aydın K, Şahin V, Gürsu S, Mercan AŞ, Demir B, Yildirim T. Effect of pentoxifylline on fracture healing: an experimental study. Eklem Hastalik Cerrahisi. 2011;22:160-165.

31. Huo MH, Troiano NW, Pelker RR, Gundberg CM, Friedlaender GE. The influence of ibuprofen on fracture repair: biomechanical, biochemical, histologic, and histomorphometric parameters in rats. J Orthop Res. 1991;9:383-390.

32. Atalay Y, Bozkurt MF, Gonul Y, et al. The effects of amlodipine and platelet rich plasma on bone healing in rats. Drug Des Devel Ther. 2015;9:1973-1981.

33. Rajkumar DS, Faitelson AV, Gudyrev OS, Dubrovin GM, Pokrovski MV, Ivanov AV. Comparative evaluation of enalapril and losartan in pharmacological correction of experimental osteoporosis and fractures of its background. J Osteoporos. 2013;2013:325693.

34. Yaman F, Atilgan S, Günes N, et al. Phosphodiesterase-5 inhibitors may facilitate bone defect recovery. Eur Rev Med Pharmacol Sci. 2011;15:1301-1305.

35. Corbett SA, Hukkanen M, Batten J, McCarthy ID, Polak JM, Hughes S. Nitric oxide in fracture repair. Differential localisation, expression and activity of nitric oxide synthases. J Bone Joint Surg Br. 1999;81:531-537.

36. Gong Y, Xu C, Wang JR, et al. Inhibition of phosphodiesterase 5 reduces bone mass by suppression of canonical Wnt signaling. Cell Death Dis. 2014;5:e1544.

37. Histing T, Marciniak K, Scheuer C, et al. Sildenafil accelerates fracture healing in mice. J Orthop Res. 2011;29:867-873.

38. Fredericks DC, Piehl DJ, Baker JT, Abbott J, Nepola JV. Effects of pulsed electromagnetic field stimulation on distraction osteogenesis in the rabbit tibial leg lengthening model. J Pediatr Orthop. 2003;23:478-483.

39. Puricelli E, Dutra NB, Ponzoni D. Histological evaluation of the influence of magnetic field application in autogenous bone grafts in rats. Head Face Med. 2009;5:1.

40. Huang YH, Polimeni G, Qahash M, Wikesjö UM. Bone morphogenetic proteins and osseointegration: current knowledge - future possibilities. Periodontol 2000. 2008;47:206-223.

41. Fassina L, Saino E, Visai L, et al. Electromagnetic enhancement of a culture of human SAOS-2 osteoblasts seeded onto titanium fiber-mesh scaffolds. J Biomed Mater Res A. 2008;87:750-759.
42. Zhong $\mathrm{C}$, Zhao T, Xu Z, He R. Effects of electromagnetic fields on bone regeneration in experimental and clinical studies: a review of the literature. Chin Med J (Engl). 2012;125:367-372.

43. Boyette MY, Herrera-Soto JA. Treatment of delayed and nonunited fractures and osteotomies with pulsed electromagnetic field in children and adolescents. Orthopedics. 2012;35:e1051-e1055.

44. Elsisi HF, Mousa GS, ELdesoky MT. Electromagnetic field versus circuit weight training on bone mineral density in elderly women. Clin Interv Aging. 2015;10:539-547.

45. Jing D, Cai J, Shen G, et al. The preventive effects of pulsed electromagnetic fields on diabetic bone loss in streptozotocin-treated rats. Osteoporos Int. 2011;22:1885-1895.

46. Hong JM, Kang KS, Yi HG, Kim SY, Cho DW. Electromagnetically controllable osteoclast activity. Bone. 2014;62:99-107.

47. Ceccarelli G, Bloise N, Mantelli M, et al. A comparative analysis of the in vitro effects of pulsed electromagnetic field treatment on osteogenic differentiation of two different mesenchymal cell lineages. Biores Open Access. 2013;2:283-294.

48. Esmail MY, Sun L, Yu L, Xu H, Shi L, Zhang J. Effects of PEMF and glucocorticoids on proliferation and differentiation of osteoblasts. Electromagn Biol Med. 2012;31:375-381.

49. Buzzá EP, Shibli JA, Barbeiro RH, Barbosa JR. Effects of electromagnetic field on bone healing around commercially pure titanium surface: histologic and mechanical study in rabbits. Implant Dent. 2003; $12: 182-187$.

50. van der Jagt OP, van der Linden JC, Waarsing JH, Verhaar JA, Weinans H. Electromagnetic fields do not affect bone micro-architecture in osteoporotic rats. Bone Joint Res. 2014;3:230-235.

51. Jing D, Cai J, Wu Y, et al. Moderate-intensity rotating magnetic fields do not affect bone quality and bone remodeling in hindlimb suspended rats. PLoS One. 2014;9:e102956.

52. Aslan A, Kirdemir V, Kocak A, et al. Influence of 1800 MHz GSM-like electromagnetic radiation exposure on fracture healing. Arch Med Res. 2014;45:125-131.

53. Okano H, Masuda H, Ohkubo C. Decreased plasma levels of nitric oxide metabolites, angiotensin II, and aldosterone in spontaneously hypertensive rats exposed to $5 \mathrm{mT}$ static magnetic field. Bioelectromagnetics. $2005 ; 26: 161-172$

\section{Publish your work in this journal}

Drug Design, Development and Therapy is an international, peerreviewed open-access journal that spans the spectrum of drug design and development through to clinical applications. Clinical outcomes, patient safety, and programs for the development and effective, safe, and sustained use of medicines are a feature of the journal, which

\section{Dovepress}

has also been accepted for indexing on PubMed Central. The manuscript management system is completely online and includes a very quick and fair peer-review system, which is all easy to use. Visit http://www.dovepress.com/testimonials.php to read real quotes from published authors. 